\title{
Biopesticides from Entomopathogenic Nematodes
}

\section{HADI KARIMIPOUR FARD ${ }^{\bowtie 1} \&$ KARIM SAEIDI ${ }^{2}$}

1. Department of Plant Protection Researches, Kohgiluyeh and Boyerahmad Agricultural and Natural Resources Research and Education Center, AREEO, Yasouj, Iran

( $\square$ Corresponding author: karimipourfard@yahoo.com)

2. Department of Plant Protection Researches, Fars Agricultural and Natural Resources Research and Education Center, AREEO, Shiraz, Iran

Received: 16.01.2019

Accepted: 18.06.2019

Karimipour Fard H. and Saeidi K. 2019. Biopesticides from entomopathogenic nematodes.

Plant Pathology Science 8(1): 60-73. DOI: 10.2982/PPS.8.1.60.

Abstract : In the recant decade, biopesticides with entomopathogenic nematodes (EPNs) have been developed with using different methods and materials. But the production of such biopesticides has always accompanied by some limitations such as low quality of the final product, and reducing the efficacy under field conditions. Recently, significant progress has been made in increasing in the survival time of these products. Applying two types of formulations, water dispersible granules and calcium alginate capsules, has increased the EPN survival time from 7 days to 180 days. As compare to aqueous formulation, the formulations based on the use of insect cadavers with EPNs, showed higher efficiency in pest control. New methods of the mass production of EPNs, using automated production lines and the use of new additives with better properties for field applications and methods in increasing the infectivity of these nematodes in pests are discussed in this article.

Key words: Heterorhabditis, Melanoplus, Steinernema

$$
\begin{aligned}
& \text { آفت كشهاى زيستى از نماتدهاى بيماركر حشرات } \\
& \text { هادى كريمى يور فردها و كريم سعيدى }
\end{aligned}
$$

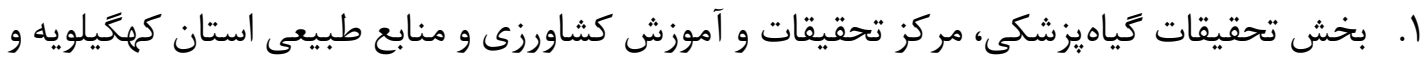

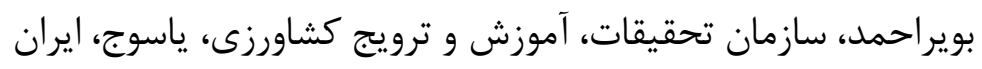

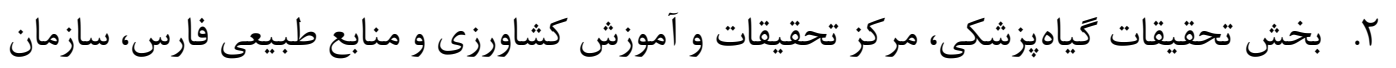

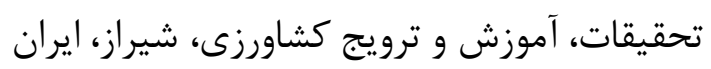

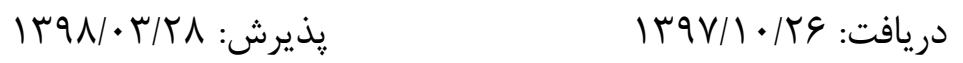

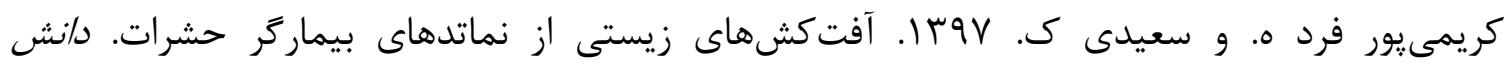

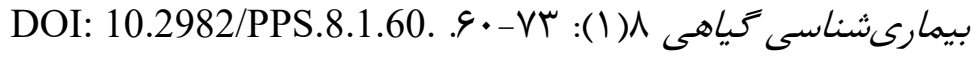


جكيده : آفتكشهاى زيستى از نماتدهاى بيماركر حشرات به روشها و با مواد مختلفى در يك دها دها

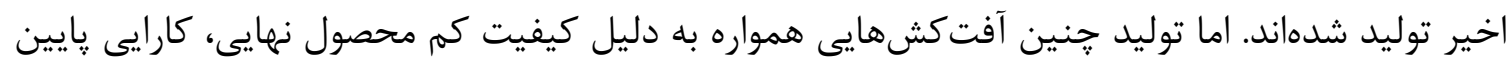

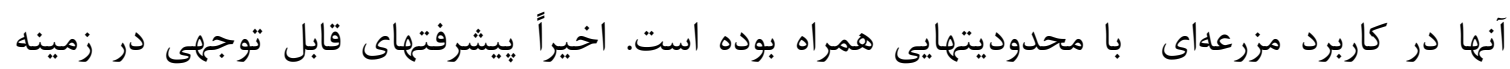

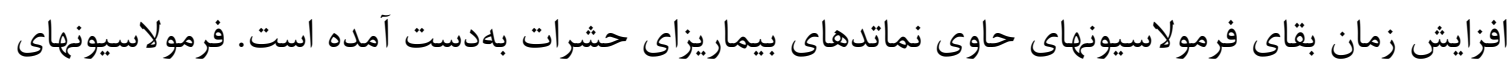

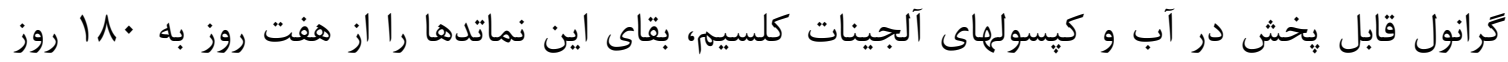

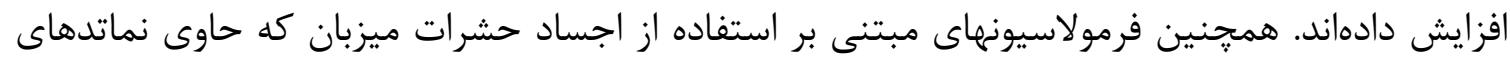

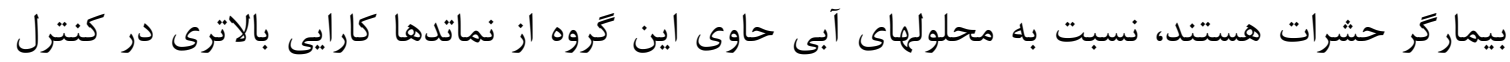

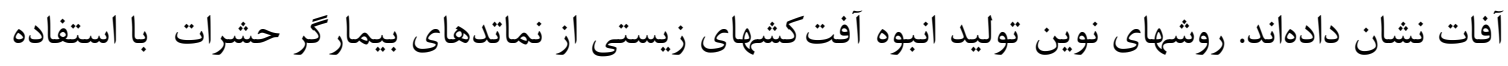

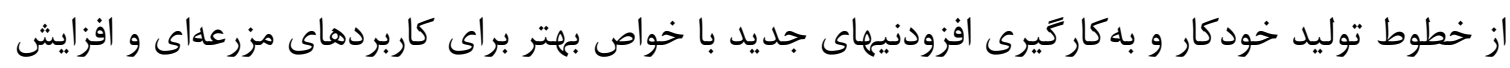

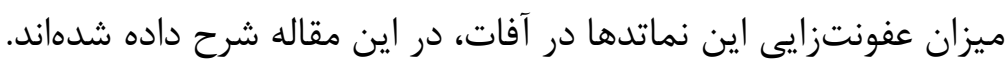
وازههاى كليدى: Steinernema ، Melanoplus،Heterorhabditis

مقدمه

مصرف بيش از اندازه آفت كشهاى شيميايى در عرصههاى كشاورزى آسيبهاى جدى به خاى، هوا، آب، مجموعههاى گياهى و جانورى و انسانها وارد كرده است. نماتدهاى بيمارگر حشرات

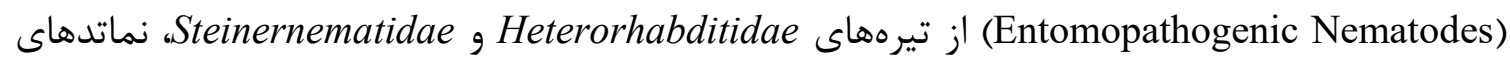
انكل اجبارى حشرات هستند كه به طور بالقوه توانايى بالايى در كنترل آفات كشاورزى دارند (Tofangsazi et al. 2014)

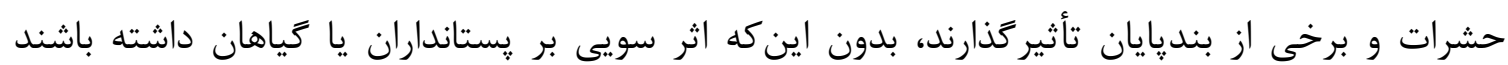

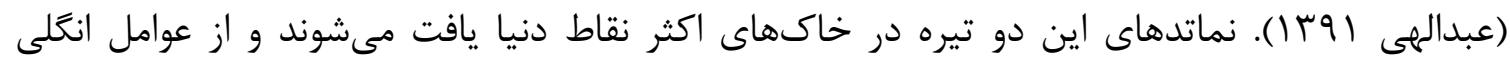
طيف وسيعى از حشرات هستند. دو جنس معروف نماتدهاى بيمارىزاى حشرات با دو جنس باكترى همراهى و همزيستى منحصر بهفردى دارند، به طورىكه جنس Heterorhabditis با باكترى جنس Photorhabdous باكترىها با نماتدهاى مذكور منجر به مرك حشرات ميزبان آنها مى گردد. زمانى كه اين نماتدها با ميزبان مناسب مواجه مىشوند، لاروهاى آزادزى و عفونتزاى آنها كه تغذيهاى از ميزبان ندارند، از طريق منافذ طبيعى مانند دهان، منافذ تنفسى و مخرج وارد بدن آنها شده و باكترىهاى همراه آنها به سرعت در الهر همولنف غنى از مواد غذايى حشرات رشد كرده و توكسينها و ساير متابوليتهاى كشنده حشرات ميزبان

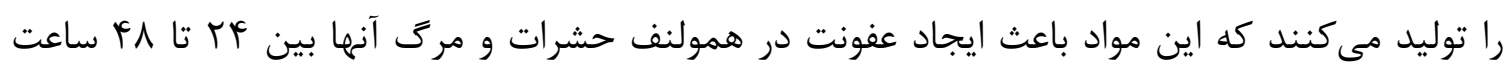


مع كردد. جنس Heterorhabditis توانايى سوراخ كردن ديواره بدن حشره و ورود به آن را نيز دارد.

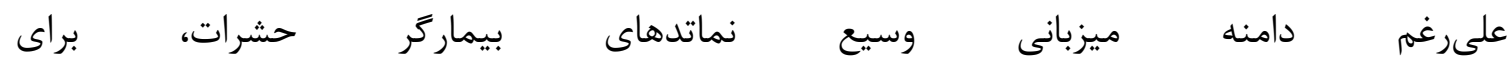
مهردداران بىخطر بوده و با روشهاى تكثير بهصورت تجارى و روشهاى استفاده عملى از آنها جهت كنترل حشرات، سازكارى دارند(Cruz-Martinez et al. 2017). محصولات تجارتى نماتدهاى بيماركر حشرات نسبت به ساير تركيبات شيميايى مورد استفاده براى كنترل حشرات، از لحاظ زيست محيطى ايمن هستند. شناخت بيشتر زيستشناسى، روشهاى توليد و ذخيرهسازى فرمولاسيونهاى مربوط به به نماتدهاى بيماركر حشرات جهت بجبود و توسعه كاربرد آنها ضرورى است. همجنين اين كونه محصولات علاوه بر اينكه قابليت اختلاط با بيشتر آفتششها را دارند، در كشورهايى مانند آمريكا معاف از ثبت آندان هستند. توليد و بهرهبردارى نماتدهاى بيماركر حشرات به منظور كنترل حشرات آفت در مقياس مزرعهاى و سطح وسيع اقدامى در راستاى كشاورزى يايدار بوده كه به كاهش مسائل و نكخرانىهاى جهانى يِيرامون

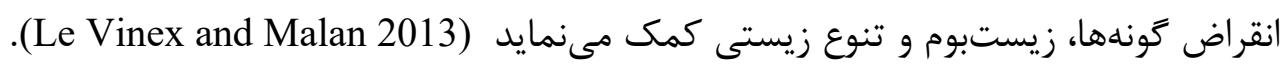

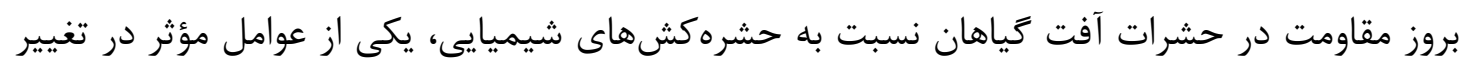

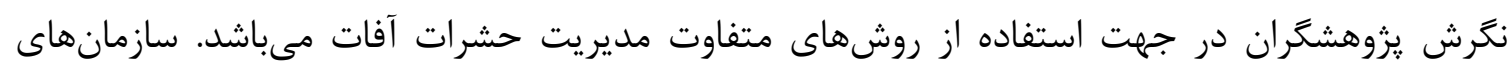

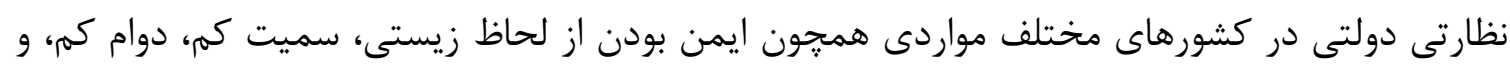

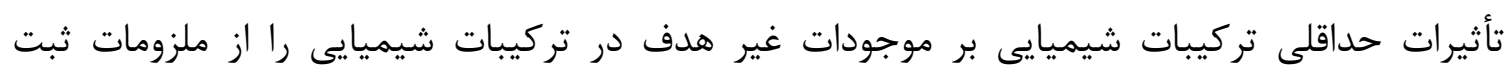
آفتكشها قرار دادهاند. مهار زيستى يكى از قوىترين و مهمترين ابزارهاى جايكزين سموم شيميايى در كنترل حشرات آفات است كه هم از لحاظ زيستمحيطى ايمن مىباشد و هم در راستاى كشاورزى پايدار

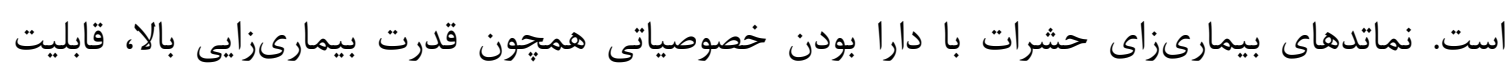

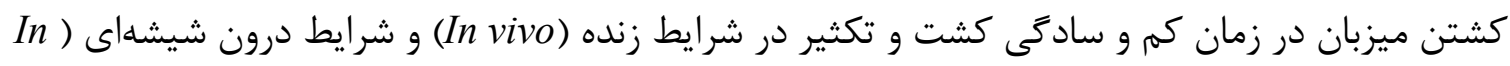

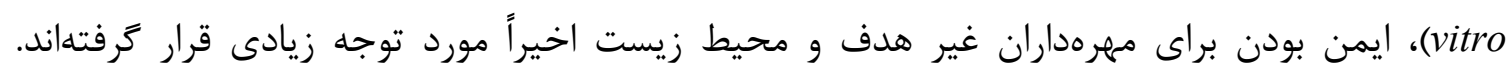
همجنين در يزوهشهاى اخير هزينههاى توليد اين نماتدها بهدليل توسعه روشهاى توليد انبوه آنها در

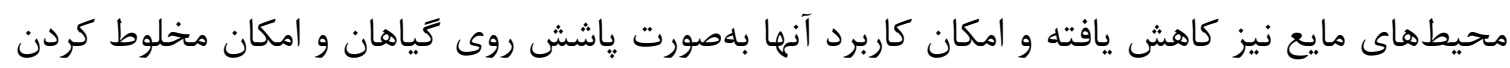

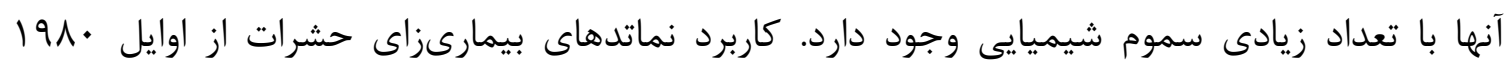

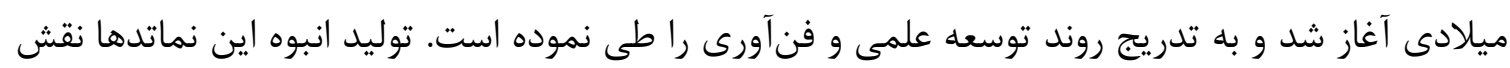
كليدى در توسعه تجارى آنها براى كنترل حشرات آفت دارد (Mahmoud 2016). 
در حال حاضر عاملهايى كه بر كاربرد نماتدهاى بيماركر حشرات تأثير گذار هستند، شامل بازار اين گونه محصولات، گياهان و حشرات هدف، فرمولاسيون و عمر مفيد آنها، دستورالعملهاى كاربرد آنها و يشتيبانى هاى تكنيكى مىباشد (Georgis et al.2006, Lacey \& Georgis 2012). فرمولاسيونها يكى از مهممترين عوامل تأثير گذار در كاربرد موفقيتآميز نماتدهاى بيمارگر حشرات به عنوان يك حشرهكش ميكروبى به شمار مىآيد. فرمولاسيونهاى نماتدهاى بيمارگر حشرات به فرايندى اطلاق مى آن نماتدهاى زنده به محصولى قابل كاربرد در مصارف عملى تبديل مىشوند. نماتدهاى بيمارگر حشرات جهت سهولت در نكهدارى، انتقال و كاربرد فرموله مىشوند (Grewal 2002). اين فرمولاسيونها بر اساس اصل حفظ انرزى ، استوار مىباشد كه براى اين منظور محدوديت در حركت يا كاهش مصرف انرزى مدنظر است. يك فرمولاسيون بهينه مىبايست خصوصياتى همجون كيفيت پايدار، سهولت در انتقال و كاربرد و تأثير بالا در كنترل آفات حشرهاى داشته باشد و به راحتى قابل استفاده در مزرعه باشد

.(Cruz-Martinez et al. 2017)

\section{ا-فرمولاسيون نماتدهاى بيماركر حشرات}

عموماً اجزاى فرمولاسيونها شامل يك جزء فعال، يك حامل و افزودنىها است. جزء فعال اين فرمولاسيونها، نماتدهاى بيماركر حشرات هستند؛ مواد حامل شامل مواد جامد، مايعات، زلها و جسد حشرات هستند. افزودنىها، مواد مختلفى با عملكردهاى متفاوت از قبيل انواع جاذبها، امولسيفايرها، سورفاكتانتها، غليظكنندهها، روان كنندها، يخشكنندهها، مواد ضد ميكروب و محافظت كنندهها در مقابل اشعه ماوراء بنفش مىباشند (Grewal 2002). هدف اصلى كاربرد افزودنىها در اين فرمولاسيونها، افزايش بقا و حفظ بيمارىزايى نماتدهاى بيماركر حشرات است (Cruz-Martinez et al. 2017). اخرجه مرحلهى بالغ برخى از حشرات نيز به فرمولاسيونهاى حاوى نماتدهاى بيماركر حشرات حساس هستند، اما اين فرمولاسيونها معمولاً براى مراحل لاروى و شفيرهىى حشراتى كه خاكزى هستند كاربرد بيشترى دارند و علت آن به رطوبت كافى در خاك براى حركت نماتد و آلوده كردن حشرات برمى اغلب فرمولاسيونها از جمله تمامى موارد نامبرده شده در بخش بعدى در زير خاك و به صورت ريختن آفتش حاوى نماتدهاى بيماركر در اطراف گياه، استفاده از نوارهاى حاوى اين نماتدها يا پخش و پاشش روى خاى در سطح وسيع استفاده مىشوند. نحوه كاربرد آفتكشهاى حاوى نماتدهاى بيماركر متناسب 
با نوع فرمولاسيون صورت مى گيرد و اين مهم به شدت در يافتن ميزبان توسط نماتد، ايجاد آلودىى و كنترل تأثير خواهد كذاشت (Devi and George 2018).

\section{ץ-انواع فرمولاسيونها جهت ذخيره و انتقال نماتدهاى بيمارَّر حشرات}

r-ا-سوسيانسيون قابل تعليق در آب: رايجترين فرمولاسيون نماتدهاى بيماركر حشرات كه عمدتاً براى ذخيره، حمل و نقل و كاربرد آنها مورد استفاده قرار مى كيرد، سوسيانسيون قابل تعليق در آب است فردات (Chen and Glazer 2005). ذخيرهسازى در دماى بين ع تا لا لا درجه سيلسيوس اين فرمولاسيونها

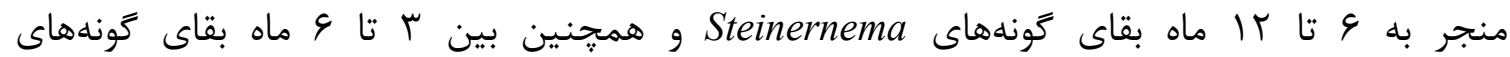
Heterorhabdus مى حشرات تأثير دارند كه مىتوان به مواردى همجون ايجاد رسوب در فرمولاسيونها، نياز به اكسيثن زياد،

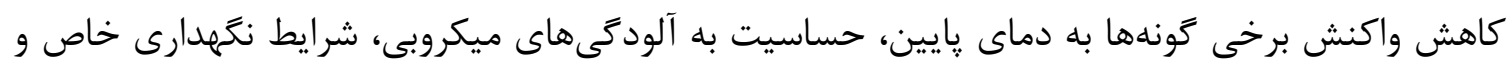

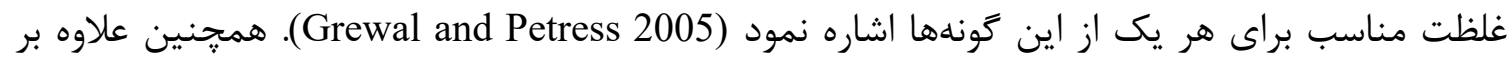
افزايش هزينهها، تأمين برودت لازم نيز مانعى براى حمل و نقل به شمار مى آيد (Grewal 2002). r- r- اسفنج مصنوعى: اين نوع فرمولاسيون شامل بهكاركيرى اسفنج يلىيورتان (Polyurethane) در

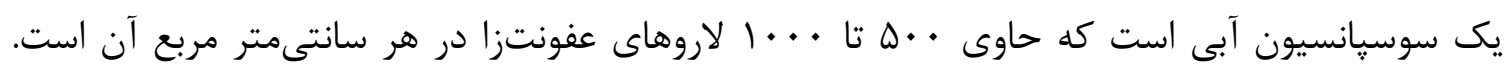
بنابراين هر اسفنج حاوى ڤنج تا ها ميليون لارو سن دوم است كه جهت نكَهدارى در يك كيسه

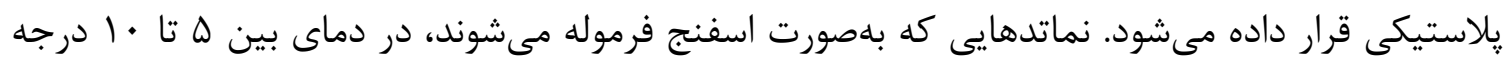

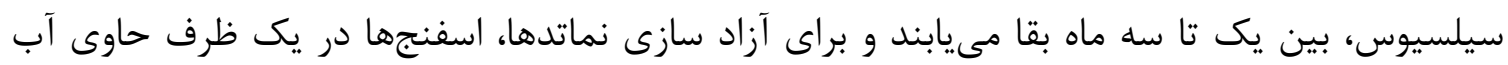

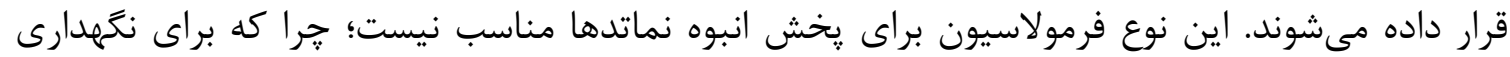
نياز به تأمين برودت دارد و زمان و نيروى كار زيادى مصرف مىشود و در نهايت مقادير زيادى ضايعات

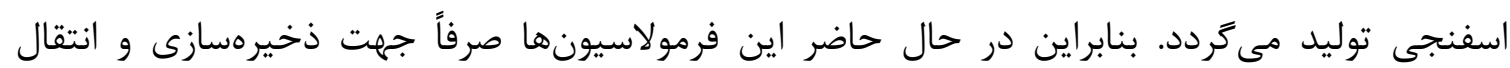
مقادير كم نماتدهاى بيماركر حشرات در جهت كنترل زيستى آفات براى مصارف خانكى مانى مانند باغجههاى خانكى در ارويا و شمال آمريكا بهكار مىروند (Cruz-Martinez et al. 2017).

r-Y- ورمىكولايت: اين فرمولاسيون نسب به اسفنج برترىهايى از جمله متراكمتر بودن محصول،

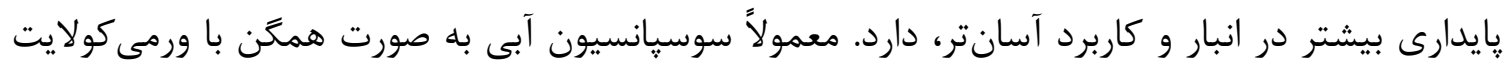


ميكرونيزه، مخلوط و اين مخلوط در كيسهاى يلىاتيلنى نگَدارى مى گردد. با اين فرمولاسيون نماتد Steinernema feltiae Filipjev r تا ها درجهى سلسيوس قابل نكَدارى است. مخلوط نماتد ورمىكولايتى مستقيماً به مخزن سمياش اضافه، با آب مخلوط و با كاهش فشار سمياش و استفاده از نازلهايى با منفذ درشت، مورد استفاده قرار مى كيرد. تنها ايراد اين فرمولاسيون عدم يايدارى محيطى است و مى بايست يس از خروج از يخهال مورد

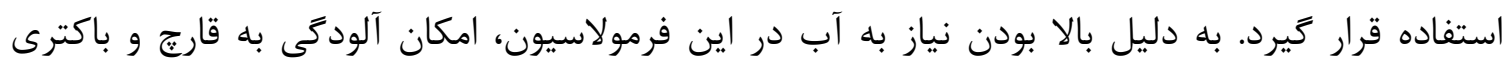

وجود دارد (Grewal and Petress 2005).

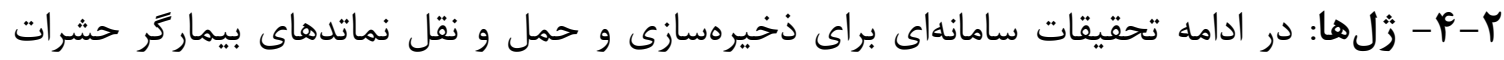

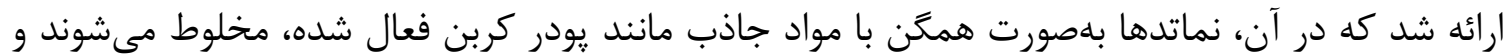
بلصورت كرم در مى آيند (Yukawa and Pitt 1985) . اما اين فرمولاسيون معايبى دارد؛ كه از آن جمله مىتوان به هزينه بالاو وإيدارى كم در دماى اتاق اشاره نمود. متعاقباً موادى با استفاده از يلى اكريل آميد

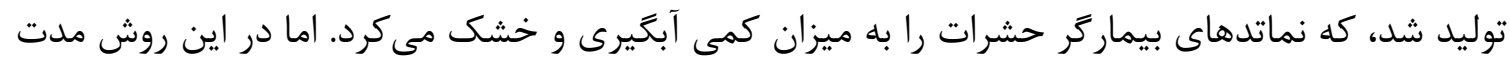
زمان بقاى نماتدها در دماى اتاق كم و مشكلاتى در زمينه حلاليت فرمولاسيونها وجود داشت (Grewal 2002; Cruz-Martinez et al. 2017) بيشرفت قابل ملاحظه ديخرى كه براى ذخيرهسازى و و نكهيدارى نماتدهاى بيماركر حشرات صورت يذيرفت، استفاده از ورقهاى آلجينات كلسيم بود كه روى صفحات پِلاستيكى يخش شده بودند. در تحقيقات ديكرى با استفاده از خميرهاى روغنى گياهى هيدروزنه حاوى مونوكليسيريد و دى كليسيريد، كيسولهايى فرموله شد كه به طور معنادارى باعث افزايش بقاى نماتدهاى بيماركر حشرات كرديدند. در تحقيقات تكميلى يك فرمولاسيون خميرى ابداع شد كه در آن كونه S. carpocapsae با روغن هيدروزنه و يلىاكريل آميد مخلوط شد، اين فرمولاسيون منجر به بقاى

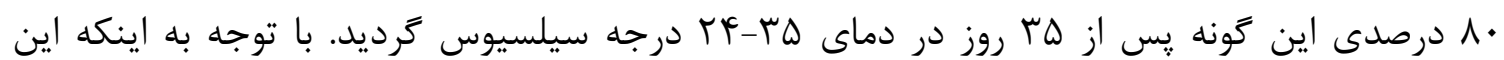
مدت زمان زندهمانى و ماندكارى فرمولاسيون از لحاظ تجارى غير قابل قبول بود، دستيابى و استفاده از

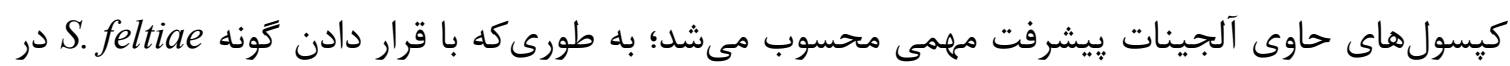

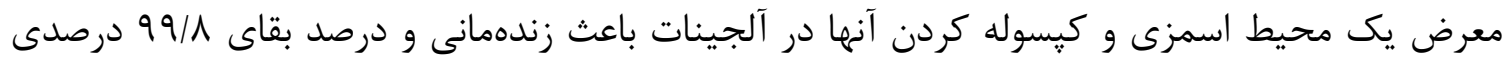
اين كونه بعد از 9 ماه در دماى بآ درجه سيلسيوس كرديد؛ اما هزينههاى بالاى تهيه اين فرمولاسيون، كاربرد آن را براى استفاده در مقياس وسيع محدود مىساخت (Cruz-Martinez et al. 2017). 
r-ه- رس و ساير يودرهاى بهصورت قرص: در فرمولاسيونهايى كه به نام فرمولاسيون ساندويجى

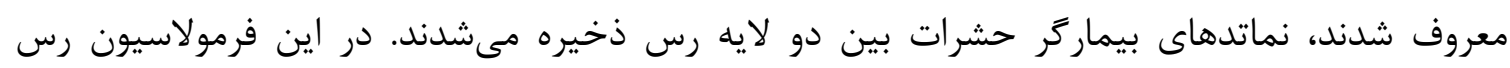
جاذب رطوبت بود ولى علىرغم عرضه اين فرمولاسيون به بازار، به علت برخى اشكالات از جمله بايدارى

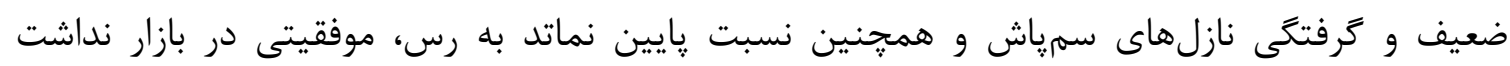

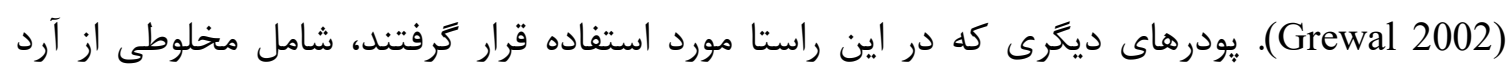

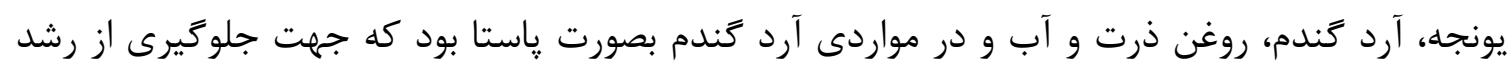

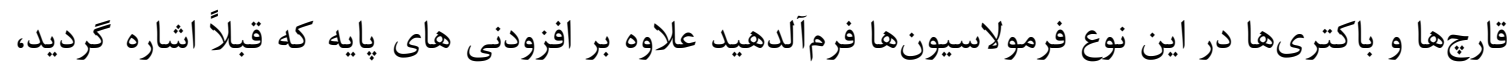
به مخلوط اضافه كرديد. همجنين جهت بهبود عملكرد فرمولاسيون كائولين نيز بعنوان ماده حامل، به فاله فرمولاسيون اضافه شد. همزمان با توليد فرمولاسيون حاوى رس، فرمولاسيونى توليد شد كه حاوى هرى

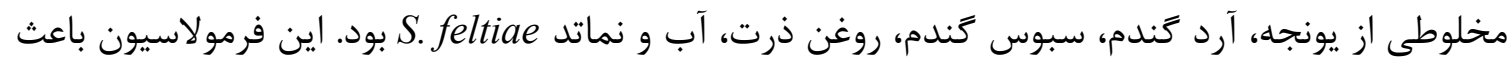

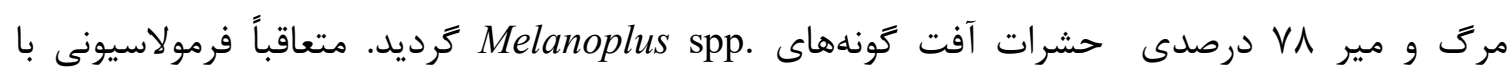

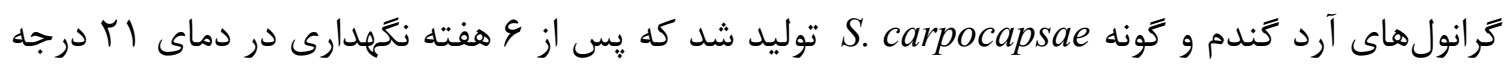
سيلسيوس نرخ بقاى يايينى داشت و علت آن رشد قارجها و باكترىها به علت وجود رطوبت و آرد كندم

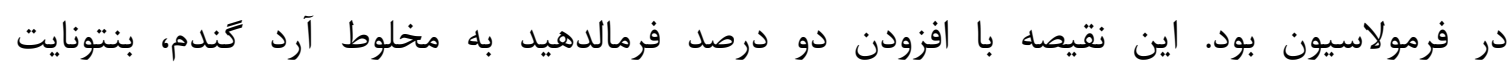

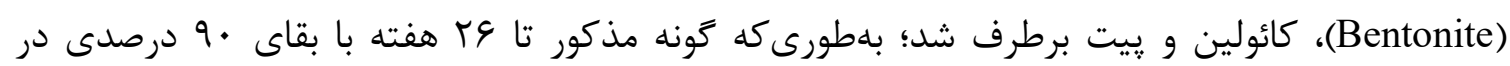

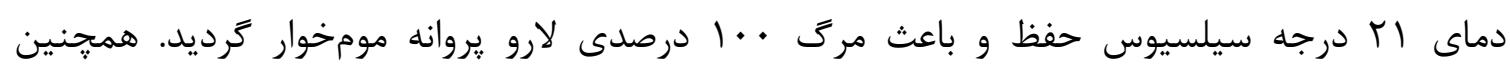

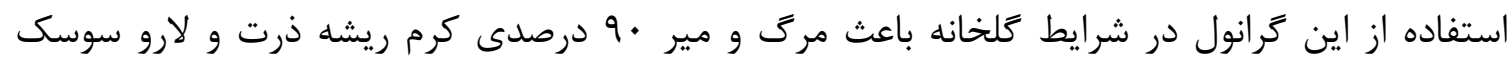

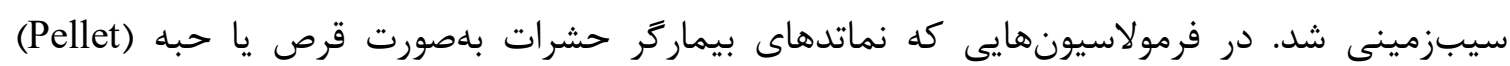
فرموله مىشوند، موارد زير در مدت بقا و حفظ توانيى آلودهسازى اين نماتدها بسيار با اهميت است: الف) خواص محيط مايعى كه اين نماتدها در آنها فرموله مىشوند، بهخصوص ميزان ويسكوزيته

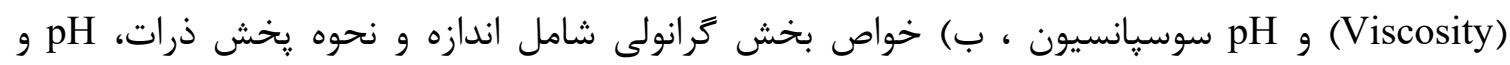
تراكم ، ج) بديدههاى فيزيكى موجود در قطعات شامل جَكونكى انتقال اكسيرن و رطوبت ، د) شرايط

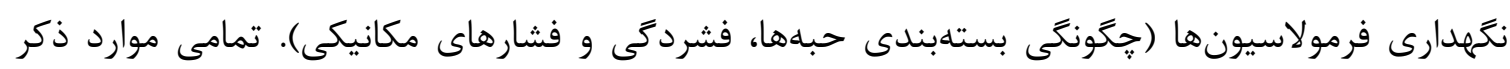

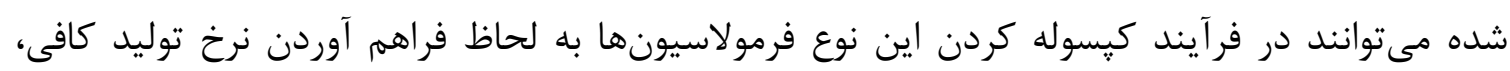
قابليت دسترسى، كاهش هزينهها و كيفيت بالا نقش داشته باشند (Cruz-Martinez et al. 2017). 


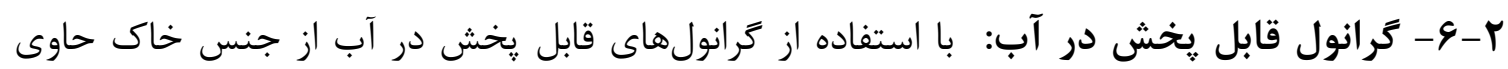

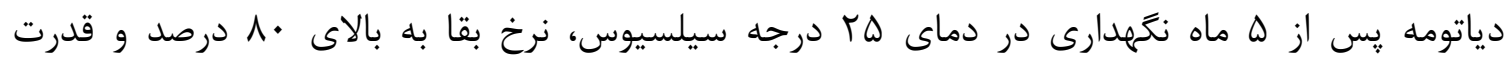
آلودهسازى حشرات به بالاى •9 درصد ارتقاء يافت. اخيرا كارايى فرمولاسيونها با كيسوله كردن كونه Steinernema glaseri Steiner

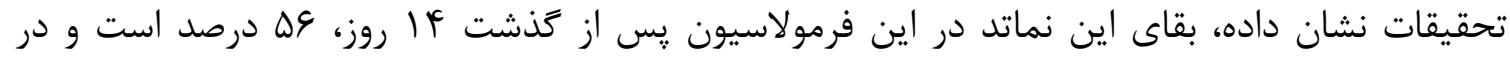

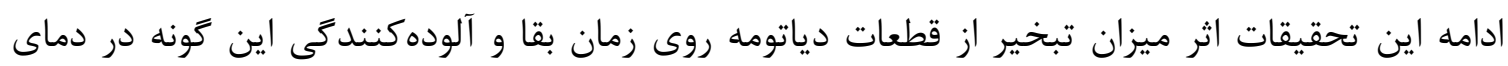
اتاق و مدل انتقال محتواى رطوبتى قطعات دياتومه از طريق انتشار و تبخير تشريح كرديد. بررسى ريز ساختارهاى قطعات حاوى دياتومه با ميكروسكوٍ الكترونى نشان داد شكل و اندازه ذرات و خصوصيات حفرات موجود در آنها يكنواخت نيست. زمانىكه قطعات حاوى دياتومه كاهش رطوبت تدريجى دارند، نماتدهاى بيماركر حشرات قادر به ورود به قسمتهايى هستند كه رطوبت وجود داشته و زمان بقاى آنها افزايش مىيابد. بنابراين محتواى رطوبتى و نرخ كاهش رطوبت قطعات حاوى دياتومه مىتواند به بايدارى اين كونه فرمولاسيونها در دماى اتاق با حفظ توانيى كنترل زيستى نماتدهاى بيماركر حشرات، كمك دائ نمايد (Cortes-Martinez et al. 2016, Cruz-Martinez et al. 2017).

\section{r- برمولاسيونهاى قابل استفاده در مزرعه}

r-1-زل: به منظورحذف معايب ناشى از آزادسازى نماتدهاى بيماركر حشرات از ترانولهاى آلجينات،

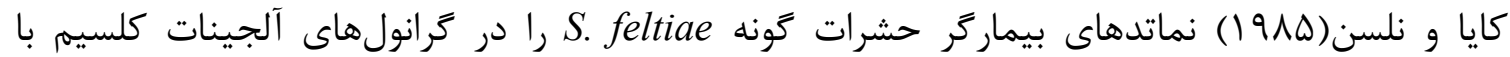
يوشش يك لايه ليجيدى بصورت كيسول شده تهيه كردند. با تغذيه لاروهاى يروانه (Huebner) Spodoptera exigua كرانولهاى آلجينات سديم حاوى S. feltiae توليد شد كه بهصورت مخلوط با بذور كوجهفرنكى عرضه كرديد. در اين فرمولاسيون بذور كوجه فرنگى يس از قرار كرفتن در معرض رطوبت جوانه زده و ساختار

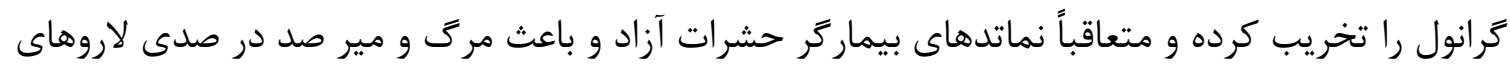
يروانه مومخوار شدند همجنين قرار دادن نماتد كونه Steinernema riobravis Cabanillas در زل مئل

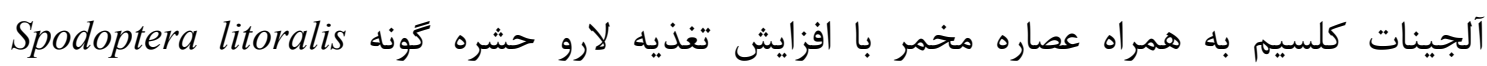
سبب كنترل صد در صدى اين كَنه كَرديد. با توجه به علاقهمندى يزوهشكران به كاربرد مستقيم نماتدهاى بيماركَ حشرات در سطح مزارع، تحقيقى در زمينه فرموله كردن نماتدهاى بيماركر 
حشرات با فرموله كردن آنها در يك يوسته آلجينات انجام شد. در اين روش محلولى با غلظت بالاى يونهاى Ca به آلجينات اضافه شد و فرمولاسيون حاصله يوستهاى كروى بود كه هسته مايع درونى را احاطه

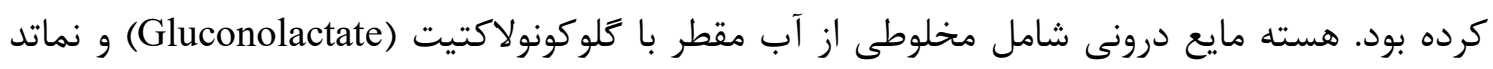
Heterorhabditis bacteriophora Poinar

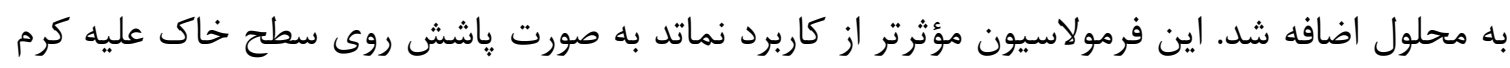
ريشه غربى ذرت Diabrotica virgifera LeConte بود (Hiltpolid et al. 2012). اشكال اين

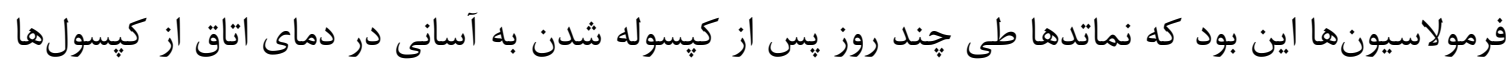
خارج شدند. اين مسئله از لحاظ تجارىسازى اين فرمولاسيون مشكلساز بود. اين مشكل با اتخاذ تدابيرى همجون تيمار ثانويه كيسولها با يون به جلو در كاربرد نماتدهاى بيماركر حشرات در مزرعه بود (Kim et al.2015). جهت دستيابى به محصول

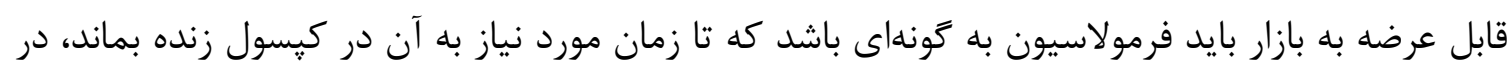
طول مدت انباردارى فرمولاسيون، خاصيت بيمارىزايى و ايجاد عفونت را حفظ و مدت زمان بقاى نماتدها

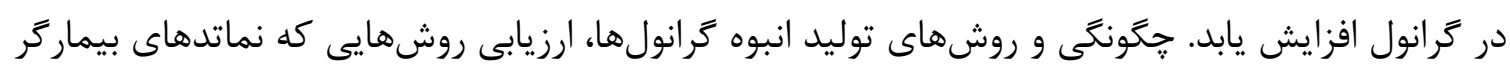

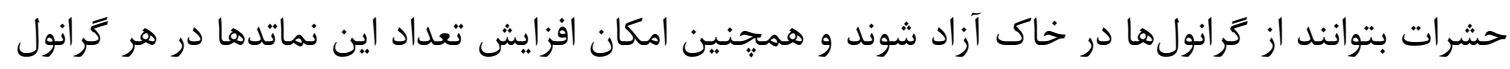

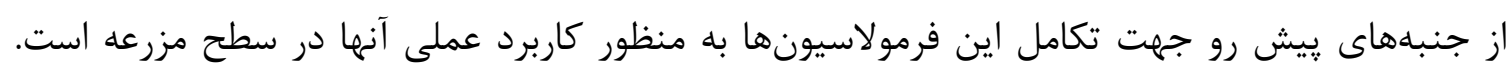

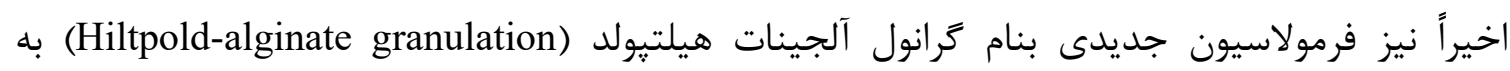

منظور كاربرد مزرعهاى نماتدهاى بيماركر حشرات معرفى شده است(Cruz-Martinez et al. 2017). r-r-r-استفاده از لاشه حشرات آلوده به نماتدهاى بيماركر حشرات : استفاده از لاشه حشرات آلوده به نماتدهاى بيمارك, حشرات يكى از راههاى كاربرد نماتدهاى بيماركر حشرات در مزرعه است (Shapiro-Ilan et al. 2008, Lacey et al. 2010, Raja et al. 2015) حشرات بهعنوان منبع ذخيره نماتدهاى بيماركر حشرات استفاده و اجساد حشرات حاوى نماتد جهت

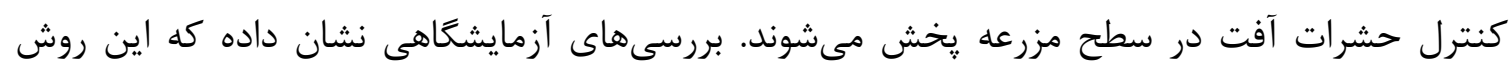

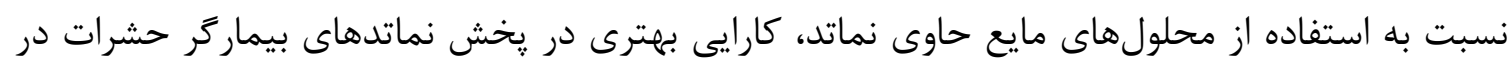

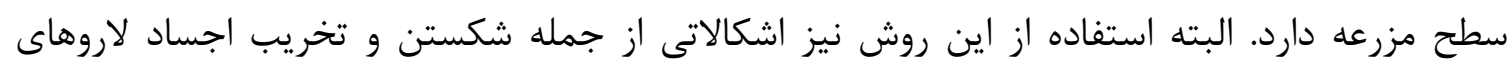

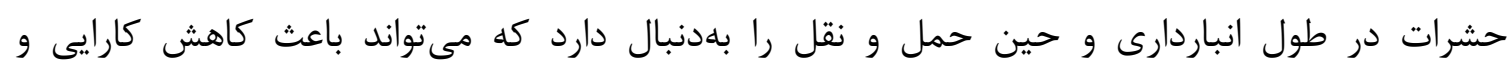


تأثير گذارى نماتدهاى بيمارگر حشرات گردد. جهت حل اين مشكل و حفظ اجساد حشرات به منظور سهولت در انباردارى و حمل و نقل، يوشش اجساد حشرات با مخلوطى از جند ماده از جمله كائولين و نشاسته و يا زلاتين بىبو (Del Valle et al. 2009, Ansari 2009, Cruz-Martinez et al. 2017) بهعنوان يك يوشش حفاظتى استفاده مى گردد. با ابداع يك روش بستهبندى ماشينى خودكار روش جايكزين ديكرى جهت جلوكيرى از تخريب اجساد حشرات حاوى نماتدهاى بيمارگر حشرات ارايه كرديده، كه طى آن اجساد حشرات در نوار مخصوصى يِيجانده مىشوند ,Shapiro-Ilan et al. 2010, (Morales-Ramos et al. 2013) شد و نتايج بررسى آنها نشان داد كه نماتدهاى بيمارگر حشرات موجود در اجساد اين حشره هيج آسيبى نديدند. استفاده از اين دستخاه مكانيكى و الكترونيكى كه بهعنوان يك نمونه اوليه ارايه شده، امكاناتى را فراهم آورده كه با بستهبندى حشرات حاوى نماتد، ضمن سهولت توليد، منجر به استاندارد شدن محصول نهايى نيز كرديد. اسينسن و همكاران (II (Y) فنآورى را معرفى كردند كه با آبخيرى و خشك كردن لاروهاى يروانه مومخوار، سهولت حمل و نقل و كار با اجساد حاوى نماتدهاى انكل حشره را فراهم آورده است. متعاقباً روشهاى ديخرى از جمله استفاده از محيط كشت . Miracle-Gro جهت كاربرد مهرد مستقيم اجساد حشرات آلوده به نماتدهاى بيماركر حشرات (Deol et al. 2011) و يا تكنيك آبخيرى و نكَهدارى در دماى سرد (Wang et al. 2014) جهت بهبود و توليد انبوه اجساد حشرات آلوده به نماتد و كاربرد آن در مزرعه ارايه گرديد. جديدترين روش ارايه شده براى كاربرد مزرعهاى نماتدهاى بيمارگر حشرات،

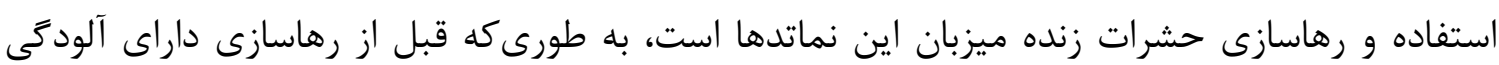
اوليه به اين نماتدها هستند(Cruz-Martinez et al. 2017). طراحى و توليد فرمولاسيونهايى از نماتدهاى بيماركر حشرات كه حاوى حشرات زنده و آلوده به نماتدهاى انگل حشرات بوده و بتوان آنها را براى استفاده در بخشهاى هوايى گياه، رهاسازى نمود، از جنبههاى مههم مطالعات فعلى ييرامون فرمولاسيونهاى نماتدهاى بيماركر حشرات است (Devi and George 2018). هرجند توليد فرمولاسيونهاى نماتدهاى بيمارگر حشرات، پيشرفت بزرگى در كنترل آفات در مزرعه محسوب مى گردد، اما موفقيت اين روش به جند عامل ضرورى بستخى دارد كه شامل تأثيرات اشعه ماوراء بنفش، رطوبت كافى خاك، رطوبت نسبى و دما بر نماتدهاى بيماركر حشرات مىباشد. بهبود كارايى و بقاى نماتدهاى بيمارگر حشرات مىتواند از طريق بهبود زنتيكى نيز به وقوع بِييوندد. ويزگگ هاى مفيد مد نظر در استرينهاى بهبود يافته نماتدهاى بيماركر حشرات شامل تحمل در مقابل شرايط زيست محيطى، 
توانايى بيمارىزايى بالا و ظرفيت توليدمثلى بالا است. همجنين استفاده از استرينهاى بومى مقاوم به شرايط خاص دمايى و رطوبتى از راهكارهاى افزايش كارايى كاربرد نماتدهاى بيمارگر حشرات در سطح

مزرعه است(Shapiro-Ilan et al. 2012, Cruz-Martinez et al. 2017).

جندين محصول تجارتى از نماتدهاى بيماركر حشرات كه در آمريكاى شمالى و ارويا توليد و به بازار عرضه شده اند در جدول ا آورده شدهاند. بيشتر اين محصولات نياز به يخجال جهت نكمهدارى و تجهيزات سمياشى جهت كاربرد در مزرعه دارند.

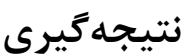

كاربرد نماتدهاى بيماركر حشرات به عنوان آفت كشهاى زيستى جديد به منظور كنترل حشـرات آفت در

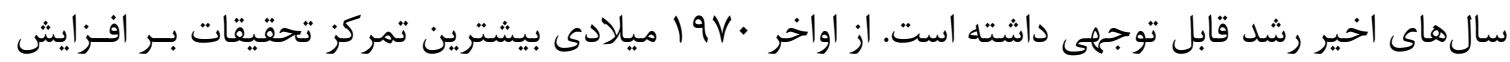

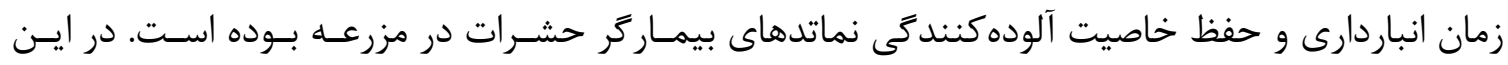

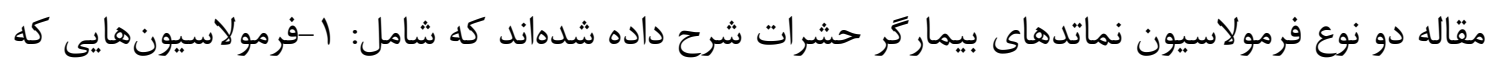

جدول ا. فرمولاسيونهاى مختلف نماتـدهاى بيمـاركر حشـرات توليـد و عرضـه شـده در ارويـا و آمريكـا

.(Cruz-Martinez et al. 2017)

Table 1. Different formulations of entomopathogenic nematodes produced in Europe and USA (Cruz-Martinez et al. 2017).

\begin{tabular}{|c|c|c|c|}
\hline نماتد** & فرمولاسيون & شركت سازنده & كشور \\
\hline $\mathrm{Ph}, \mathrm{Sf}, \mathrm{Sc}, \mathrm{Hb}, \mathrm{Sk}$, & يليمر، رس & BASF & آلمان \\
\hline $\mathrm{Sf}, \mathrm{Hb}, \mathrm{Sc}$ & يليمر، رس & e-nema $\mathrm{GmbH}$ & آلمان \\
\hline $\mathrm{Hb}, \mathrm{Sc}, \mathrm{Sf}$ & رس & Andermatt Biocontrol & سوئيس \\
\hline $\mathrm{Sf}, \mathrm{Hb}, \mathrm{Sc}, \mathrm{S}$ sp. & يليمر، رس & Koppert & 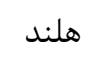 \\
\hline $\mathrm{Sc}, \mathrm{Sf}$ & رس & Asa Jung Laboratory & 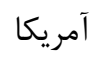 \\
\hline $\mathrm{Sc}, \mathrm{Sf}, \mathrm{Hb}$ & كرانول قابل پِخش در آب، & BioLogic & 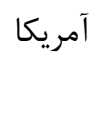 \\
\hline Sc, Sf, S sp., H sp. & اسفنج & Hydro-Gardens & 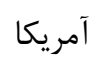 \\
\hline $\mathrm{Sc}, \mathrm{Sf}, \mathrm{Hb}$ & اسفنج & M \& R Durango & 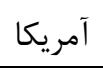 \\
\hline
\end{tabular}

* $\mathrm{Ph}=$ Phasmarhabditis hermaphrodita, $\mathrm{Sf}=$ Steinernema feltiae, $\mathrm{Sc}=$ Steinernema carpocapsae, $\mathrm{Hb}=$ Heterorhabditis bacteriophora, $\mathrm{Sk}=$ Steinernema kraussei , $\mathrm{S} \mathrm{sp} .=$ Steinernema sp., H sp.= Heterorhabditis sp. 
به منظور ذخيره و انتقال توسعه يافتهاند و ييشرفتهاى قابل ملاحظهاى در زمينه افزايش زمان بقـاى ايسن

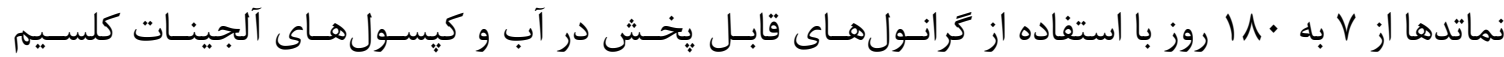
هستند. Y- فرمولاسيونهايى كه جهت كاربرد مستقيم در مزرعـه توليـد مسىشـوند. ايسن فرمولاسـيونهـا قابليت كاربرد مستقيم نماتدهاى بيمارگر حشرات را بهعنوان يكى آفت كث زيسـتى بـراى كنتـرل حشـرات آفت در مزرعه فراهم مى آورند و شامل اجساد حشرات حـاوى نماتـدهاى بيمـاركر حشـرات و گرانـولهـاى آلجينات ميىباشند. اين در حالى است كه همجنان امكان بهبود گرانولها (بهصورت حبههـاى حساوى رس و يودر) به عنوان فرمولاسيونهايى كه بتواننـد ريـز سـاختارهاى بهينــهاى جهــت نغَهـدارى و حمـل و نقـل حشرات را فراهم آورند، وجود دارد. يزوهشهاى انجام شده در زمينه افزايش زمان انباردارى و بهبــود شـيوه حمل و نقل فرمولاسيون اجساد حشرات حاوى نماتدهاى بيمارگر حشرات نشان داداند كه يوشـشدهـى و خشك كردن اجساد حشرات حاوى نماتدهاى بيمارگر، ييجاندن اجساد حشرات در نوار مخصوص و معرفىى فرمولاسيون جديدى بنام گرانول آلجينات هيلتيولد، را براى تسـهيل كـاربرد مزرعـهاى ايسن آفت كشـهاى زيستى ي بيشنهاد كرد.

\section{References}

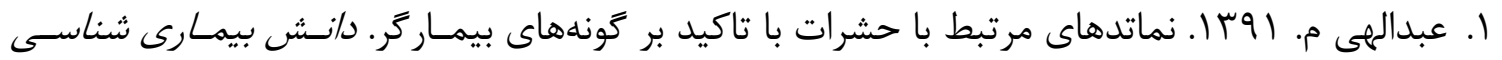
F

2. Ansari M.A., Hussain M.A., Moens M. 2009. Formulation and application of entomopathogenic nematode-infected cadavers for control of Hoplia philanthus in turfgrass. Pest Management Science 65: 367-374.

3. Chen S., Glazer I. 2005. A novel method for long-term storage of the entomopathogenic nematode Steinernema feltiae at room temperature. Biological Control 32: 104-110.

4. Cortés-Martínez C.I., Ruiz-Vega J., Matadamas-Ortiz P.T., Lewis E.E., AquinoBolanos T., Navarro-Antonio J. 2016. Effect of moisture evaporation from diatomaceous earth pellets on storage stability of Steinernema glaseri. Biocontrol Science and Technology 26: 305-319.

5. Cruz-Martinez H., Ruiz-Vega J., Matadamas-Ortiz P.T., Cortés-Martinez C.A. and Rosas-Diaz J. 2017. Formulation of Entomopathogenic nematodes for crop pest control - a review. Plant Protectection Science 53(1): 15-24.

6. Del Valle E.E., Dolinski C., Barreto E.L.S., Souza R.M. 2009. Effect of cadaver coatings on emergence and infectivity of the entomopathogenic nematode 
Heterorhabditis baujardi LPP7 (Rhabditida: Heterorhabditidae) and the removal of cadavers by ants. Biological Control 50: 21-24.

7. Deol Y.S., Jagdale G.B., Canas L., Grewal P.S. 2011. Delivery of entomopathogenic nematodes directly through commercial growing media via the inclusion of infected host cadavers: a novel approach. Biological Control 58: 60-67.

8. Devi G. and George J. 2018. Formulation of Insecticidal Nematode. Annual Research \& Review in Biology 24 (5): 1-10.

9. Georgis R., Koppenhöfer A.M., Lacey L.A., Bélair G., Duncan L.W., Grewal P.S., Samish M., Tan L., Torr P., van Tol R.W.H.M. 2006. Successes and failures in the use of parasitic nematodes for pest control. Biological Control 38: 103-123.

10. Grewal P.S. 2002. Formulation and application technology. Pp. 265-287. In: R. Gaugler (ed.). Entomopathogenic Nematology. Oxfordshire, CABI.

11. Grewal P.S., Peters A. 2005. Formulation and quality. Pp. 79-90. In: P.S Grewal., R.U Ehlers., D.I. Shapiro-Ilan (eds.): Nematodes as Biocontrol Agents. Oxfordshire, CABI.

12. Hazir S., Kaya H.K., Stock S.P., Keskin N. 2003. Entomopathogenic nematodes (Steinernematidae and Heterorhabditidae) for biological control of soil pests. Turkish Journal of Biology 27: 181-202.

13. Hiltpold I., Hibbard B.E., French B.W., Turlings T.C.J. 2012. Capsules containing entomopathogenic nematodes as a Trojan horse approach to control the western corn rootworm. Plant and Soil 358: 11-25.

14. Kaya H.K., Nelsen C.E. 1985. Encapsulation of Steinernematid and Heterorhabditid nematodes with calcium alginate: a new approach for insect control and other applications. Environmental Entomology 14: 572-574.

15. Kaya H.K., Aguillera M.M., Alumai A., Choo H.Y., de la Torre M., Fodor A., Ganguly S., Hazir S., Lakatos T., Pye A., Wilson M., Yamanaka S., Yang H., Ehlers R.U. 2006. Status of entomopathogenic nematodes and their symbiotic bacteria from selected countries or regions of the world. Biological Control 38: 134-155.

16. Kim J., Jaffuel G., Turlings T.C.J. 2015. Enhanced alginate capsule properties as a formulation of entomopathogenic nematodes. BioControl, 60: 527-535.

17. Lacey L.A., Georgis R. 2012. Entomopathogenic nematodes for control of insect pests above and below ground with comments on commercial production. Journal of Nematology 44: 218-225.

18. Le Vieux P. \& Malan, A.P. 2013. Entomopathogenic nematodes for the control of the vine mealybug (Planococcus ficus) in South African wine and table grapes: A review. South African Journal of Enology and Viticulture 34, 108-118.

19. Mahmoud M.F. 2016. Biology and use of entomopathogenic nematodes in insect pests biocontrol, a generic view. Cercetări Agronomice în Moldova, Vol. XLIX, No. 4 (168): 85-105. 
20. Morales-Ramos J.A., Tedders W.L., Dean C.B., Shapiro- Ilan D.I., Rojas M.G. 2013. Apparatus for packaging arthropods infected with entomopathogenic nematodes. U.S. Patent No. US 8,505,236.

21. Raja R.K., Hazir C., Gümüs A., Asan C., Karagöoz M., Hazir S. 2015. Efficacy of the entomopathogenic nematode Heterorhabditis bacteriophora using different application methods in the presence or absence of a natural enemy. Turkish Journal of Agriculture and Forestry 39: 277-285.

22. Shapiro-Ilan D.I., Tedders W.L., Lewis E.E. 2008. Application of entomopathogenic nematode-infected cadavers from hard-bodies arthropods for insect suppression. U.S. Patent No. 7,374,773.

23. Shapiro-Ilan D.I., Morales-Ramos J.A., Rojas M.G., Tedders W.L. 2010. Effects of a novel entomopathogenic nematode-infected host formulation on cadaver integrity, nematode yield, and suppression of Diaprepes abbreviates and Aethina tumida. Journal of Invertebrate Pathology 103: 103-108.

24. Shapiro-Ilan D.I., Han R., Dolinksi C. 2012. Entomopathogenic nematode production and application technology. Journal of Nematology 44: 206-217.

25. Spence K.O., Stevens G.N., Arimoto H., Ruiz-Vega J., Kaya H.K., Lewis E.E. 2011. Effect of insect cadaver desiccation and soil water potential during rehydration on entomopathogenic nematode (Rhabditida: Steinernematidae and Heterorhabditidae) production and virulence. Journal of Invertebrate Pathology 106: 268-273.

26. Tofangsazi N., Cherry R.H., Arthurs S.P. 2014. Efficacy of commercial formulations of entomopathogenic nematodes against tropical sod webworm, Herpetogramma phaeopteralis (Lepidoptera: Crambidae). Journal of Applied Entomology 138: 656-661.

27. Wang X., Wang H., Feng Q.-Z., Cui X.-Y., Liu R.-Y., Sun Y.-B., Li G.-C., Tan H., Song D.-M., Liu W., Ruan W.B., Harvey J.A. .2014. Desiccation and cold storage of Galleria mellonella cadavers and effects on in vivo production of Steinernema carpocapsae. Pest Management Science 70: 895-904. 